\title{
VII. 自己抗体検出とその臨床的意義
}

\section{1.甲状腺疾患における甲状腺自己抗体}

千葉大第一外科

永野 耕士, 武田 清一
小川 清, 伊藤健次郎

各種甲状腺薙患の甲状腺自己抗体を剆定し癌および腺 隀の自己抗体と組織所見特にリンパ球浸潤およびリンパ 港胞形成の有無との関連を検討した。 また末梢血 T細 胞，B細胞との関係について調べてみた．マイクロゾー ムに対する抗体(MCHA)，サイログロブリンに対する抗 体 (TGHA) は富士藏器のマイクロゾーム，サイロイド テストキットにて測定し，102 以上を陽性とした．T細 胞は $\mathrm{E} ロ セ ゙ ッ ト ， \mathrm{~B}$ 細胞は $\mathrm{EAC}$ ロゼット形成にて測定 した. MCHA, TGHA 陽性率は, 慢性甲状腺炎62 例で は93.2\%，65.6\%，㐫セドウ氏病19例，93.3\%，44.4\% 甲状腺癌 40 例， $33.3 \% ， 23.3 \%$ ，腺腫 54 例 $30.0 \%, 6.0$ \%である. 抗体洒は腺腫・癌では低値のものが多い，腺 腫では，非腫湯部にリンハ濾胞形成の明らかなものは，

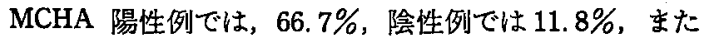
TGHA 陽性例では，100\%，陰性例では，25.0\%であ り, MCHA おょび TGHA の出現は $\mathrm{p}<0.01$ でリンパ 演胞形成との間に関連がみられる.また，MCHA，TGHA 陽性例は，リンパ球浸閏の見られるものが多いが統計的 に有意の差はみられない。甲状腺癌では, MCHA の出 現と非癌部甲状腺のリンパ球浸潤およびリンパ濾胞形成 との間には，関連がみられない，リンパ球浸潤の認めら れるむのは，TGHA 陽性例では $62.5 \%$ ，陰性例は 12.5 \%で $\mathbf{p}<0.05$ で関連がみられる．またりンパ滤胞形成 の明らかなむのは TGHA 陽性例では $87.5 \%$ ，陰性例で は20.8\%で $\mathrm{p}<0.01$ で関連がみられる，癌巣周辺のリ ンパ球浸閏，リンパ㴧胞形成と自己抗体との間には関連 はない. MCHA，TGHA の出現および抗体価とリンパ 球数， $\mathrm{T}, \mathrm{B}$ 細胞百分率数との間には特に関連はみられ ない.

\section{2. バゼドウ病におけるヒト甲状腺刺激性抗体に วいて}

京大核医学放射線科

小西 淳二，笠木 寛治, 鳥塚 莞爾
神戸中央市民病院内科

森徹

バセドゥ病患者血中に存在する TSH 結合阻害性 IgG (TSH-binding inhibitor immunoglobulins, TBII) は TSH 受容体に対する抗体と考えられているが，この抗 体の病因的意義を明らかにするため，その甲状腺刺湤作 用を検索し，患者甲状腺の adenylate cyclase (AC) 活 性や臨床所見との関連, さらに治療後の変動について検 討を行った.

方法：TBII は TSH の radioreceptor assayを用い て測定し，IgG のヒト甲状腺 AC 刺激作用 (HTACS) はOrgiazzi らの変法により測定した。患者甲状腺の AC 活性は針生検により得た組織の粗膜分画を用いて測定 し，TSH $(10 \mathrm{mU} / \mathrm{ml})$ に対する反応性を併せ検討した.

結果：バセドウ病患者に利る TBII 活性はHTACS と有意の正相関を示L，甲状腺 ${ }^{90 \mathrm{~m}} \mathrm{~T}_{\mathrm{c}}$ 摂取率，甲状腺 組織の增殖所見との間にも明らかな相関関保が認められ た. 未治療バセドウ病甲状腺12例の AC 活性は平均 2.76 \pm 0.57 ( SD) p mols cAMP/mg wet weight $/ 10 \mathrm{~min}$ で 正常甲状腺の $1.25 \pm 0.46$ 飞比べ有意に高く，TSH 剌 激による増加率は正常甲状腺に比へ低值であった，12例 中 7 例 $(58.3 \%)$ HTACS が検出されたが，血中 HTACS 陽性群では陰性群に比して甲状腺 AC 活性が有 意に高值であった，治療により甲状腺 $\mathrm{AC}$ 活性は低下 乙，血中 HTACS \& $T_{3}$ 抑制試験陽性となった 5 例では 1 例の弱陽性を除き陰性であった。

以上の成績はパセドウ病甲状腺が剌激性抗体により実 際に刺激されている事を強く示唆する。

3. 血中抗甲状腺抗体陽性の臨床的意義

阪大中央踟床検査部

網野 信行, 畔立子, 森英光

宮井潔

岩手医大第一病理

吉田 博, 上村 邦紀, 矢川 寛一

目的：血中自己抗体の测定は自己免疫疾患の診断に極 めて重要であるが，血中抗体が陽性であってもそれに関 与する疾病の臨床症状が明らかでない場合，その臨床的 
意義づけは必ずしも明らかにされていない。この様な場 合潜在する自己免疫疾患が存在する，あるいは免疫反応 系の異常により疾病とは関倸なく自己抗体加出現する， または組織抗原と交叉性を有する疾病とは無関係の抗原 物質に対する抗体を測定している等の可能性が考えられ る，今回我々は抗甲状腺抗体を例炕とり，無症状時の抗 体の意義つけにつき検討を行なった。

方法：いわゆる健常人 754 人を対象に血中抗サイログ ロブリン抗体，抗マイクロゾーム抗体を测定し，同時に 臨床所見を観察した，非甲状腺疾患者70例に扩りる剖検 時での血中抗体と甲状腺組織りンパ球浸潤の有無を比烄 した. 橋本病が出産後增恶することから (Clin exp Immunol 31,30，1978），血中抗甲状腺抗体のみ陽性で臨 床症状・所見のみられない女性における出産後の変化を 観察した.

結果：いわゆる健常成人の男性の $4.2 \%$ ，女性の $8.5 \%$ に抗サイログロブリン抗体又は抗マイクロゾーム抗体の 陽性がみられ，これらの女性の $40 \%$ に軽度甲状腺腫大を 認めた. 剖検例で血中抗体と甲状腺リンパ球浸㵎の有無 とがよく一致した. 抗体のみ陽性の女性の出産後に甲状 腺機能異常が認められた. 以上のことから一般健常人に おける抗甲状腺自己抗体陽性例では潜在性自己免度性甲 状腺炎が存在するむのと考えられた。

4. 新しい抗核抗体・非ヒストン蛋白抗体についての 検討

\section{埼玉医大第一内科}

荒尾 俊夫, 蔵 和夫, 畔柳 武雄

目的，方法；抗核抗体の検出には種々の核材が用いら れるが，核材に上り検出される場合とされない場合があ る. 我々は溃光抗体および酸素抗体法により或る種の核 材で抗核抗体陰性，他の核材で陽性を示す 4 症例を経験 した. 核材はラット肝凍結切片, ラット腹水肝癌細胞, こワトリ肝凍結切片, 鵎赤血球, 牛胸腺の凍結切片を用 い検討した.

結果：4症例は Speckled 型もしくは nucleolar 型 で，他の核材では，すべて 640 倍以上の抗核抗体価を示 したが，鵎赤血球を核材にした場合は全く検出得しなか った．そこで核材の核抗原粗成を検討したところ，鵎赤 血球では非とストン蛋白及び RNA が非常に低い事が知 られた. しかるに牛胸腺の核材でむRNAが非常に低い 事から，これら 4 例の抗核抗体陽性者の抗核抗体は核の 非ヒストン蛋白成分にある可能性が示唆されたこれら
4 症例は，抗 DNA 抗体および抗ヒストン抗体は陰泩, 血球凝集法による抗非ヒストン抗体偄は12,000 24, 000 倍と高い凝集樋を呈した，症例は 4 例中 3 例はARAの 診断基準を满たす SLE で腎障害は伴なわず，溶血性盆 血，血小板减少などの血液学的異常を伴なっていた，残 り 1 例は進行した PSS にも拘わらず腎障害はみられて いない: 現在，非ヒストン部分について詳細に検討中で ある.

\section{5. 抗 RNP, 抗 Sm 抗体の検出と臨床的意義} 岡山大第三内科

河本 紀一, 宮脇 昌二
倉田 典之, 大藤 真

目的：抗 RNP, 抗 Sm 抗体の検出法, および SLE K おける臨床的意義について検討した（侩出法の検討） $0.14 \mathrm{M} \mathrm{Nacl}$ に上る幼若家鬼胸腺抽出物 (RT), 仔牛胸 腺核抽出物 (CTNE), ラット肝抽出物 (RLE), 同核抽 出物 (RLNE) を抗原とし，標準血清を用いた免疫拉散 法では, RT, 次いで CTNE, RLNE に RNP, Sm 抗原 が多く認められ，同時に他の多種抗原も存在した．しか し組織夜の長時間の Sonication および頻回の洗浄は特 に RNP を失活させる傾向があった， RT を抗原とした 免疫拡散法は，血球凝集反応 (PHA) で16倍陽性という 低い抗体洒を示す血清中の抗 RNP，抗 Sm 抗体をも飧 出可能であった. PHA は抗 RNP, 抗 Sm 抗体以外にも 抗 MU, 抗 SS-B, 抗 Scl-1, 抗 KM, 抗 TM, 他 unknown antigen に対する抗体の 1 部子検出し，その識別は不能 であった，免疫拡散法は高感度で，SLE 150 例中，抗 RNP，抗 Sm 両者陽性（グループ1）は31\%，抗 RNP のみ陽性 (グループ2) は25\%，抗 RNP，抗 Sm 両者 陰性（グループ 3) は $45 \%$ と従来の報告に比し陽性頻度 は高かった（臨床的意義の検討)グループ1は 3 K比 し，レイノー現象 $(63: 25 \%)$ ，ステロイド使用後に多 い中枢神経症状 $(37: 13 \%)$ が高頻度で，LE 現象(50： $75 \%)$ が低頻度であった. グループ2は3に比しレイノ 一現象 $(76: 25 \%)$, 中权神绎症状 (38:13\%) が高頻 度で, LE 現象 $(46: 75 \%)$, 腎症 $(24: 74 \%)$, n-DNA 結合能上㫒 (46:64\%)，CH 50 低下 (41:75\%) が低 頻度であった.

\section{6. 抗 s8-DNA，IgE 抗体と IgE リゥマチ因子 一飞の検出法と病因論的, 臨床的意義一 阪大第三内科}


八倉 隆保, 山村 雄一

目的 : $\operatorname{IgE}$ 抗体は，血管透過性の元進を惹起させるこ とから、いわゆる immune complex disease の発現過 程において immune complex の沈着に前駆的な役割を 演ずるものと推定されている.この観点から，われわれ は IgE クラスの自己抗体の自己免疫疾患における病因 論的意義汇強い関心をもち，まずその検出・测定法を確 立することを目的として一連の研究を行っている.今回 は, 抗 ss-DNA IgE 抗体扰よびIgE リウマチ因子 (IgE RF)について報告した。

方法：ss-DNAに対する IgE 抗体は， CNBr-活性化 Sepharose 4B K ss-DNA をカップルさせた solid phase を用いる RAST 法により radioimmunoassay した. IgE RF の測定は, heat-aggregated RGG(ウサギIgG) を CNBr-佸性化 paper disc に結合せしめこれに結合 する IgEを RAST 法に準じて radioimmunoassay す る方法によった．いずれの抗体の場合でも，健常人対照 プール血清で得られたカゥントに対する被検患者血清で 得られたカウントの比（カウント比）を算出し， RAST 法の通例にもとついてカウント比が 2.0 またはそれ以上 の場合を $\operatorname{IgE}$ 抗体陽性と判定した。

結果：抗 Ss-DNA IgE 抗体はSLE 患者の約 20\% K 認められた. SLE 以外の賿原病では，2.0以上のカウン ト比を示す症例はなかった．IgE RF と考えられる血清 因子は RA で13例中 2 例に，SLE で23例中 4 例に認め られた. 興味あることに，高い抗体洒を示したRAの1 例は臨床的には MRA であった。

\section{IgG 抗リンパ球抗体の検出}

\section{東大物療内科}

䓵原 忠夫, 竹内 明輝, 奥平 邦雄

柏戸 敬道, 橋本 明, 堀内 淑彦

研究目的：抗リンパ球抗体 (ALS) は，自己免疫病の 発症進展に, 重要な役割をしていると考えられてきてい る.一般に, ALSは, IgM型で, 低温で強く反応する. 一方，リンパ球機能の修飾，影響には，IgG 型 ALS が 重要であるとの報告もある. 我々は, より生理的な $37^{\circ} \mathrm{C}$ で反応させる系で，IgG-ALS の検出を試み，生物学的 意義の検討を目的とした。

方法 : IgG 抗体を介して起きる鋭敏な免疫反応である ADCC の系を使い， ${ }^{51} \mathrm{Cr}$ の遊離で抗体を挨知した. 即 ち， ${ }^{51} \mathrm{Cr}$ でラベルしたヒト末梢血リンパ球を標的細胞と
し，熱非動化した正常人，患者血清を $37^{\circ} \mathrm{C} 2$ 時間培兹 した後，効果細胞としてマゥス脾細胞を加え，更に20時 間培羡し， ${ }^{5 s} \mathrm{Cr}$ の遊離を測定し，細胞障贵性より，抗 体の検出を行った.

成績 : (1)正常人 8 例では ${ }^{51} \mathrm{Cr}$ の遊離は, $-2.2 \pm 4.8$ \%で，7.4\% 以上を陽性とした。 (2)シェーグレン病 $4 / 8$, SLE 4/11，他の膠原病1/19で，陽性であった. (3.IgGALS は，SLE 患者では低補体価，リンパ球減少を伴う 㑯向にあった。 【陽性血清の分画では，IgG 分画に，抗 体活性を認めた。

総括：IgG-ALS は，我々の用いた方法により模出可 能で, シェーグレン, SLE で高率にみられた。輪血歴 のない男性患者でむ陽性であった事より，抗 HLA 抗体 ではないと考市られる，その生物学的意義は，今後に残 された課題で, 現在検討中である.

8. 結腸癌と多発性筋炎の合併例にみられた新しい未 同定抗体の検討

$$
\begin{aligned}
& \text { 名保衛大内科 } \\
& \text { 宮地 清光 } \\
& \text { コロラド大内科 }
\end{aligned}
$$

Tan E. M.

目的：結腸癌摘出後の患者が 5 年目に定型的多発性筋 炎の症状を呈した，CEA は陰性，癌の転移はなかった が，血清中に末同定で高抗体価の抗体が出現していた。 そこで対応抗原の性状を明らかにし，本抗体の意義を検 討した.

方法：抗体の検索は，ラット肝クリオスタット切片， ヒト Bリンパ芽球様細胞（wi12），七下喉頭癌上皮細胞 (HEP II) を用いた間接螢光抗体法(IF) と，ラット肝， 幼若家鬼胸腺 (RT), wi12 細胞より抗原抽出し, 二重免 疫拡散法によった。 PM-1 標準血清は G. C. sharp よ り分与されたものを用いた，対応抗原の性状は，免疫電 気泳動法，種々のナル分画法を用い検討し.た。

成績：1)本血清はラット肝を用いた IF 法で Speckied (sp), Nucleolar(No) 抗体が弱陽性, wil 2, HEP II で Sp. No 抗体とも強陽性を示した. 2) 二重免疫拡散法で ラット肝抽出抗原と反応せず， RT 抽出抗原と弱く， wil 2 抽出抗原と強く反応した，3）抗原は, 電気易動 度 $a_{1}$, グロブリン，分子量 10〜15万，塩浱度 $0.25 \sim$ $0.35 \mathrm{M}$ で分画された，4）膠原病患者血清 150 血清につ き本抗体を検索したが，1 例も同定出来ず，本抗体は 
PM-1 抗体とも異っていた，5）剖倹で肉眼的癌転移は なかった．対応抗原の性状から胎児珄癌抗原に対する抗 体が考觉られ，今後の臨床的検討が必要と思われた。

9. 多発性筋炎 (PM) における自己抗体と病型 度大内科

三森 経世，稲田 進一

山縣 元, 秋月 正史 都立大久保病院り $=ー マ$ チ膠原病科 和田伊津子

目的：沈降抗体の特異性による多発性筋炎 $(\mathrm{PM})$ の病 型分類を目的とした:

方法: Medsger の基準による PM 59 例を対象とし仔 牛胸腺抽出物を用い免疫拡散法で沈降抗体を検索した。 標準血清（抗 RNP, Sm, SS-A, SS-B 抗体）で特異性を 同定 - 分類 ᄂ, 臨床症状, 免疫学的特徵, 治療反応性, 予後等を比較検討した。

成績 : 既知の抗体之異なる 2 種類の沈降抗体 $(\mathrm{Ku}, \mathrm{Su}$ system)を見出し，SLE と PSS 各67 例の検索ではKu は各 1 例にのみ陽性，Su は全例に陰性であった。これ らの抗体を含め沈降抗体の出現様式によりPMを 5 群に 分類した. I 群は RNP 抗体陽性の17例で全例が SLE を 重複し 5 例が MCTD に該当, I群は Ku 抗体陽性の 7 例で全例が PSS との重複を示し，四群は Su 抗体陽性の 8 例で高頻度の肺線維症の合併を特徵とし， $\mathrm{N}$ 群は他の 未同定抗体陽性の 9 例で典型的 PM • DM に加方少数の 全身缄器症状を持つ例があり，V群は沈降抗体陰性の18 例で典型的 PM ・DM と考えられた. 沈降抗体を持たな いV群が本来のPM と考兄られ，これに種々の自己抗体 が加わって新たな症状が出現し病像を修飾する可能性が 示唆された。

結語：PMに特異的と考えられる2 種類の沈降抗体を 見出した. Sharp らの PM-1, Reichlin らの Mi との 異同は現在検討中である.PM の病像, 治療, 予後を考 える上で自己抗体に基く病型分類は重要と思われる.

\section{0. 強皮症にみられる新しい自己抗体に関する検討} 名保衙大内科

宮地 清光, 浜本 龍生, 鈴木 定 杉浦 元孝, 鳥飼 勝隆, 梅田 博道 同中检

前野 芳正，鈴木 悦子
目的：PSS において近年 Tan らが，本又邦において 東条らが抗 Scl-1, Og 抗体の疾患特異性について報告し ている.この抗 Scl-1 抗体の頻度, 特異性ならび臨床的 意義について榆討した，又本年米国りウマチ学会で諸 井，Tan 等が報告した新しい自己抗体 Guildersleeve (Gu) Kついても検討した.

方法 : Medsger 基準の Probable, Definite PSS 12 例を対象とし，各種結合組織疾患71例，正常人54例を対 照とした。抗体の梌少はIF 法, エールリッと腹水癌， 上卜胎児肺細胞，人Ｏ型白血球，ニワトリ赤血球ラッ ト肝切片を核材とした：二重免废拡散法は抗原として幼 若家鬼胸腺抽出物 (RTE) 及び人肝抽出液 (HLS) を用 い標準血清との一致により同定した.

成績 : IF に批いて培養細胞を核村とした場合 Homogeneous 型を中心傐頻度に陽性を示し他の核材では低 率であった. 又均等徵細な Speckled 型を示す抗 Gu 抗体 が 2 例認められた. かつエールリッヒ腹水癌細胞抽出液 を用い二重免疼应散法で検出できた. PSS 12例は RTE 及び HLS と反応し抗 Scl-1 抗体陽性は 7 例 58\%であり 他は低率であった. 又他の結合組織疾患71例及び正常人 54例において抗 Scl-1 抗体は険出されなかった. 本抗体 陽性例は皮涽硬化の顕著な例に多く認められた。

結諭：培養細胞を用いた IF 法により抗核抗体が高率 に検出され. その有用性が考えられた. 又抗 Scl-1 抗体 の疾患特異性が再確認され，抗 $\mathrm{Gu}$ 抗体の病因的意義に ついて検討を加える予定である。

\section{1. 悪性實血亡抗胃抗体} 慈恵医大青戸分院内科

名越 温古, 広田孝比古, 田中 信夫 悪性分血(PA)に出現する抗胃抗体は内因子抗体(IFA， I 型 : Blocking antibody $と$ II 型 : Binding antibody) 及び胃壁細胞抗体 (PCA) がある.これら抗体の臨床的 意義と細胞障害性の面から，PA の発生機序につき考察 した．抗胃抗体の発生顈度を全国 131 機関につき行った 調査でみると，IFA I 型，50.6\%，II 型 $28.8 \%$, PCA 82. $5 \%$ で年令別には PA の好発年令にやや先行してい る. 次に胃粘膜状態と抗体出現率るるると，胃粘膜の萎 縮が高度になるに従って抗体洒の低下，とくに IFA 陰 性例が增加してくる.これはPAに执いて一部に抗体出 現をみない一因と考える。この点につき我々は潜在性恶 性鿓血の 1 例を経験している.すなわちこの患者は PA 
の発症以前に PCA，IFA の陽性をみており，約 1 年目 KPA の臨床症状, 所見を得たが一方抗体価は徐々に減 少さらに陰性化した例である。次にこれら抗体の細胞障 害性につきラットを用いた実験では，壁細胞数，内因子 活性等に有意に減少がみられたが，䠄床的にはいまだ解 明されていない点が多い，以上より PA の発症につき我 タは，萎縮珄胃炎の隻行がまず扢こり，IFA，PCA の出 現，やや途れて内因子の分泌低下，さらに $\mathrm{VB}_{12}$ の吸収 障害と枯喝がおこり貧血となると考え, 抗体の出現は病 態推移の二次的現象と考えているが遺伝的背景等の問題 が残されており，今後詳細な検討が必要と考える. 又 PCA は他のの多くの疾患でも出現する為，PAに括い ては IFA がその臨床的意義がつよいと考える。

\section{2. 肝疾患における抗コラーゲン抗体}

鳥大第二内科

周防 武昭, 中井一化, 平山 千里

目的：肝のコラーゲンは I 型と四型コラーダンで構成 されているが，正型コラーゲンは存在しない，今回，わ れわれは各種肝疾患について血清中の I 型, II 型および II 型コラーゲンに対する抗体を検索した結果, 肝疾患の らち慢性活動性肝疾患ではとくにI型と正型コラーゲン に対する抗体が高率に出現する成績をえたので報告す る.

方法：血清中の抗コラーダソ抗体はタンニン酸処理ヒ ッジ赤血球凝集反応にて険索しだ. 抗原としたコラーダ ンのらち，I型と正型はウシ皮膚より， II 型はウシ軟骨 より分離精製した. 高力価を示した血清を各こラーゲン およびヒト IgG, IgM 抗血清で吸取し力価の変動をみ た. また Sephadex G-200 によるゲルろ過法にて, 本 抗体の分布を検討した。

結果と考案：正常者ではほとんど抗体は検出されなか った. 急性肝炎と慢性持続性肝炎では正常者と差はなか ったが, 慢性活動性肝炎, 肝硬变および原発性肝癌では 陽性率, 力価とも高かった。本抗体は I 型, II 型, II 型 コラーダンいずれに対しても各々特異的に出現したが, I 型と自型に対してょり優位であった，本抗体は IgG と IgM 抗体であり，r゙グロブリンと相関した. 以上の 成續より肝疾患に怙ける抗コラーゲン抗体はある程度診 断的意義をむっている. 本抗体は絧内系の機能異常やB 細胞系の機能充進により非特異的に生成されるが，肝内 に增加したコラーゲンに対応して生成される可能性も示 唆される.
司会者報告

\section{札幌医大癌研内科 \\ 福田 守道 \\ 市立札幌病院内科 \\ 松山隆治}

演題は12題，甲状腺 3 題，SLEなど抗核抗体 4 題，之 の他の膠原病, 自己免疫疾患 5 題で, 病態と自己抗体の 関連に関するむのが多く所期の目的に適ったワークショ ップとなった.

まず甲状腺に関し，千葉大永野は甲状腺抗体陽性例之 リンパ污胞形成, リンパ球浸潤の相関が腺腫で明瞭で, 癌では周囲甲状腺にリンバ汇胞のみが見出されるとし， 京大小西は TBII が HITAC と正相関を示し, 摘出組 織内 adenyl cyclase 活性とよく相関することからバセ ドゥ病で本抗体が実際に刺激効果を示すと推定した．阪 大網野は正常例に战ける甲状腺抗体陽性例が女性に有意 に高く $(8.5 \%)$, この中に subclincal thyroiditis が含 まれることから抗体検索の意義を強調した，抗核抗体に 関しては，埼玉医大荒尾が，SLEなどで核材により異な る反応珄を示す non histone 蛋白抗体が見出されると し，岡大河本は膠原病における RNP，Sm 抗体活性の検 索より，とくに RNP 抗体が MCTD, Sicca complex で 高率に陽性化すると述べた。阪大八合は IgE type の抗 ss-DNA，抗 RF の RIA 法に上る検索成續を報し，東大 节原は IgG type ALS A ADCC 法により検出し， Sjögren, SLE に陽性例を見出している。 また名保衛大 宮地は Denver 大にて経験した結腸癌手術例に合併し たPMで特異な抗体活性を見出したと報じた.

自己抗体と病像の関係で注目されたのは，度大三森の 報告で，PM 54例に各種自己抗体を検索し，抗体出現態 度により4群に分けられること，それぞれSLE, PSS 合 併，予後不良例，抗体陰性の経過佳良性などの特徵を有 すると報した．PSS と自己抗体については名保衛大前 野が Scl-1 抗体の疾患特異性を強調し，慈恵大名越が悪 性筫血に㧍ける内因子抗体の意義お よび latent PA 発 見の可能性を指摘したままた鳥取大周防は肝疾患におけ る collagen I, III 抗体を検索, CAH, LC などで陽性 率が上昇することを強調した。 